https://doi.org/10.17816/MAJ191S163-65

\title{
RELATIONSHIP OF NERVOUS AND IMMUNE SYSTEMS IN PATIENTS WITH CHRONIC MERCURY INTOXICATION
}

\author{
G.M. Bodienkova', ${ }^{1, \text { O.L. Lakhman }}{ }^{1}$, E.V. Boklazhenko', S.I. Kurchevenko ${ }^{1}$, E.V. Katamanova ${ }^{1}$
}

${ }^{1}$ East-Siberian Institute of Medical and Ecological Research, Angarsk, Russia;

${ }^{2}$ Irkutsk National Research Technical University, Irkutsk, Russia

\section{НЕЙРОИММУННЫЕ ВЗАИМООТНОШЕНИЯ У ПАЦИЕНТОВ ПРИ ХРОНИЧЕСКОЙ РТУТНОЙ ИНТОКСИКАЦИИ}

\author{
Г.М. Бодиенкова ${ }^{1,2}$, О.Л. Лахман ${ }^{1}$, Е.В. Боклаженко ${ }^{1}$, С.И. Курчевенко ${ }^{1}$, Е.В. Катаманова ${ }^{1}$ \\ ${ }^{1}$ ФГБНУ «Восточно-Сибирский институт медико-экологических исследований», Ангарск; \\ ${ }^{2}$ ФГБОУ ВО «Иркутский национальный исследовательский технический университет», Иркутск
}

The purpose of the study was to identify the dependencies between the content of cytokines, neuronal antibodies and changes in the bioelectrical activity of the brain in patients with neurointoxication with mercury, depending on the severity of the pathological process. Surveyed men with professional chronic mercury intoxication I-II degree - 17 people and 33 - with ChMI III degree. The serum ELISA was used to determine IL-1 $\beta$, IL-4, IL-8, IL-10, TNF- $\alpha$, INF- $\gamma$, and AT to nerve tissue proteins (NF-200, GFAP, S-100, MBP, MAG, B-end. Ca-canal, B2GP, DNA, Glu-R, GABA-R, DA-R, Ser-R, AH-R). Visual evoked potentials were evaluated on an electroencephalograph. As a result of the research, the peculiarities of the relationship between cytokines and neuronal antibodies, indicating the initiation or regulation of immunopathological reactions depending on the degree of ChMI, were revealed. When ChMI I-II Art. IL-1 $\beta$ hyperproduction was accompanied by an increase in AT to Ser-R, B-head Ca-channel and a decrease in AT to Glu-R. In patients with ChMI III degree a decrease in IL-1 $\beta$ is associated with increased production of antibodies to S-100, and a decrease in TNF- $\alpha$ with increasing antibodies to NF-200, GABA-R, GFAP. In patients with ChMI with high levels of antibodies to S-100, a more pronounced delay in the appearance of the response of the cortex to the visual stimulus, an increase in the latency of P200 was revealed. Thus, the obtained data confirm the complex functional relationships between the nervous and immune systems, the selectivity and selectivity of damage to the structures of the nervous tissue at various stages of ChMI, which can serve as unique biomarkers.

Keywords: mercury; neurointoxication; cytokines; antibodies; electroencephalography.

Цель исследования заключалась в выявлении зависимостей между содержанием цитокинов, нейрональных АТ и изменением показателей биоэлектрической активности головного мозга у пациентов с нейроинтоксикацией ртутью в зависимости от степени выраженности патологического процесса. Обследованы мужчины, с профессиональной хронической ртутной интоксикацией (XРИ) I-II ст. - 17 человек и 33 - с ХРИ III ст. Методом ИФА в сыворотке крови определяли IL-1 $\beta$, IL-4, IL-8, IL-10, TNF- $\alpha$, INF- $\gamma$, АT к белкам нервной ткани (NF-200, GFAP, S-100, ОБM, MAG, B-зав. Са-канал, Б2ГП, ДНК, Глу-Р ДА-Р, Сер-Р, АХ-Р). Зрительные вызванные потенциалы (ЗВП) оценивали на электроэнцефалографе. В результате исследований выявлены особенности взаимоотношений цитокинов и нейрональных АТ свидетельствующие об инициации или регуляции иммунопатологических реакций в зависимости от степени ХРИ. При ХРИ I-II ст. гиперпродукция IL-1 $\beta$ сопровождалась возрастанием АТ к Сер-Р, В-зав.Са-каналу и снижением АТ к Глу-Р. У пациентов с ХРИ ІІІ ст. снижение IL- $1 \beta$ сопряжено с усилением продукции AT к S-100, а снижение TNF- $\alpha$ с увеличением AT к NF-200, ГАМК-P, GFAP. У пациентов с ХРИ с высокими уровнями АТ к S-100, выявлено более выраженное запаздывание времени появления реакции коры на зрительный стимул, увеличение латентности Р200. Таким образом, полученные данные подтверждают сложные функциональные взаимосвязи между нервной и иммунной системами, селективность и избирательность поражения структур нервной ткани при различных стадиях ХРИ, которые могут служить уникальными биомаркерами.

Ключевые слова: ртуть; нейроинтоксикация; цитокины; антитела; электроэнцефалография.

Introduction. In recent years, the mechanism of regulation by the central nervous system (CNS) of the immune system, and vice versa, is of particular interest when exposed to neurotoxicants. An important role in this interaction belongs to cytokines, neurospecific proteins. Antibodies (AB) on the one hand, participating in the processes of dysregulation, can be one of the reasons for the development of, on the other - to act as endogenous protective substances [1].

The purpose of the study was to identify the dependencies between the content of cytokines, neuronal antibodies and changes in the bioelectrical activity of the brain in patients with neurointoxication with mercury, depending on the severity of the pathological process. 
Material and methods. 50 men were examined with occupational chronic mercury intoxication (ChMI) who were undergoing indepth examination and treatment at the clinic of the Institute. Including: 17 persons with ChMI I-II degree, characterized mainly by asthenoneurotic syndrome (at the age of $49.60 \pm 1.3$ years, with work experience in contact with mercury $21.65 \pm 1.61$ years). 33 patients with ChMI of III degree (age $-53.38 \pm 0.82$ years, experience $15.62 \pm 0.8$ years) in the clinical picture of which encephalopathy dominates. The diagnoses were established by the doctors of the Clinic on the basis of the classification criteria for diseases and conditions of the $10^{\text {th }}$ revision. Pro-, antiinflammatory cytokines (IL-1 $\beta$, IL-4, IL-8, IL-10, TNF- $\alpha$, INF- $\gamma$ ) were determined in the serum by ELISA using test systems of Vector Best (Novosibirsk), neurotropic IgG class AT to nerve tissue proteins (NF-200, GFAP, S-100, MBP, MAG, B-end. Ca-canal, B2GP, DNA, GABA-P, Glu-R, DA-R, Ser-R, AH-R) ("Immunculus", Moscow). Determination of visual evoked potentials (VEP) and their components was carried out on a DX-NT $32 \mathrm{~V} 1.9$ computer electroencephalograph (manufactured by DX-Complexes LTD, Kharkov). Statistical processing of research results was carried out using the software package Statistica 6.0.

Results and discussion. In previous studies, we have shown that the development and course of mercury neurointoxication is accompanied by a disturbance of the cytokine balance, a change in the levels of neuronal $\mathrm{AB}[2,3]$. As a result of these studies, the features of the relationship between cytokines and antibodies to the regulatory proteins of the nervous tissue were revealed. IL-1 $\beta$ hyperproduction was accompanied by an increase in $\mathrm{AB}$ to Ser-R $(r=0.74 ; p=0.01)$, a B-end Ca-canal $(r=0.70 ; p=0.02)$ and a decrease in $\mathrm{AB}$ to Glu-P $(r=-0.64 ; p=0.04)$ in patients with ChMI I-II degree. Decrease in IL- $1 \beta$ correlated with increased production of $\mathrm{AB}$ to $\mathrm{S}-100(r=-0.42 ; p=0.04)$, and a decrease in TNF- $\alpha$ with increasing AB to NF-200 $(r=-0.56$; $p=0.005)$, GABA-P $(r=-0.51 ; p=0.01)$ and GFAP $(r=-0.44 ; p=0.03)$ in patients with ChMI III stage. The results indicate the initiation or regulation of immunopathological reactions, depending on the degree of ChMI. When studying the VEP in patients with ChMI with high levels of $A B$ to $\mathrm{S}-100$ protein, a more pronounced delay in the appearance of the response of the cortex to the visual stimulus and an increase in the latency of P200 (ChMI I-II degree $-r=0.43 ; p=0.02$, ChMI III degree $-r=0.76 ; p=0.03$ ).

Conclusion. Thus, the obtained data confirm the complex functional interrelations between the nervous and immune systems, the selectivity and selectivity of damage to the structures of the nervous tissue at various stages of ChMI, which can serve as biomarkers in diagnosing the severity of mercury neurointoxication.

\section{References}

1. Sozaeva DI, Berezhanskaya SB. The main mechanisms of interaction of the nervous and immune systems. Clinical and experimental data. Kuban Scientific Medical Herald. 2014;3:145-150.

2. Bodienkova GM, Boklazhenko EV. Dynamics of changes in neurotropic antibodies induced by exposure to metallic mercury vapor. Modern problems of science and education. 2016;2: http://science-education.ru/ $\mathrm{ru} /$ article $/$ view? id $=24425$.

3. Bodienkova GM, Boklazhenko EV. Patterns of cytokine production with chronic exposure to physical and chemical production factors. Occupational Medicine and Industrial Ecology. 2017;9:26-27. 